Sharif University of Technology
Scientia Iranica
SCIENTIA
I RAN I C A
http://scientiairanica.sharif.edu

\title{
Empirical evaluation of cyclic behavior of rotational friction dampers with different metal pads
}

\author{
M. Anoushehei ${ }^{a}$, F. Daneshjoo ${ }^{a, *}$, S. Mahboubi ${ }^{b}$, and M.H. Hashemi ${ }^{c}$ \\ a. Department of Civil and Environmental Engineering, Tarbiat Modares University, Tehran, Iran. \\ b. Department of Civil Engineering, Shahid Beheshti University, Tehran, Iran. \\ c. Department of Mechanical Engineering, SAAB Steel Development Co., Qazvin, Iran.
}

Received 21 August 2016; received in revised form 15 February 2017; accepted 8 July 2017

\author{
KEYWORDS \\ Experimental \\ analysis; \\ Passive energy \\ dissipation; \\ Rotational friction \\ damper; \\ Cyclic loading; \\ Hysteresis behavior.
}

\begin{abstract}
Passive energy dissipation devices are widely used to reduce maximum responses of structures under seismic loading. Recently, different types of passive energy devices have been developed to improve seismic behavior of structures in new construction and retrofitting existing structures. Friction dampers are displacement-dependent passive devices which dissipate energy using friction mechanism. Many different types of friction dampers have been proposed in recent years. This paper aims to investigate the cyclic behavior of a rotational friction damper with different friction pads under cyclic loading. To this end, experimental analysis is performed on a friction damper with four friction materials. The tested damper consists of steel plates, friction pads, preloaded bolts, and hard washers. Cyclic loads are applied to damper specimens with four friction pads: aluminum, galvanized steel, stainless steel, steel (St-37). The experimental results are studied according to FEMA-356 acceptance criteria to select appropriate friction materials as friction pads for use in the friction damper.
\end{abstract}

(C) 2018 Sharif University of Technology. All rights reserved.

\section{Introduction}

Passive energy dissipation devices have been recently used in new construction and rehabilitation of existing structures to reduce the damage made to them due to earthquake excitement [1]. Researchers normally employ many different mechanisms to develop passive energy dissipation devices including metals yielding, phase transformation of metals, friction, deformation of viscoelastic materials, and fluid orificing [2]. Friction dampers are displacement-dependent passive energy

\footnotetext{
*. Corresponding author. Tel.: +982182883384

E-mail addresses: majid.anoushehei@modares.ac.ir ( $M$. Anoushehei); danesh_fa@modares.ac.ir (F. Daneshjoo); sh_mahboubi@sbu.ac.ir (S.Mahboubi); mh.hashemi@saabsteel.net (M.H. Hashemi).
}

dissipation devices which dissipate energy by means of friction caused by the slippage between two surfaces in contact. The behavior of friction dampers is influenced by the normal load and the friction coefficient of two bodies sliding towards each other. Friction coefficient is an intrinsic characteristic of surfaces and depends on adhesion, ploughing, and the presence of contaminants [3]. Many studies have been performed on friction dampers. Pall and Marsh [4] proposed a friction damper located at the intersection of braces and utilized asbestos brake lining between steel sliding surfaces. This damper consists of several steel plates clamped together with high strength bolts, allowed to slip under a determined load. Constantine et al. [5] introduced a friction damper which utilized two friction pads and sliding shafts. Tremblay and Stiemer [6] proposed a friction damper in which friction was developed through the sliding of steel surfaces and bolted 
slotted plates located at the end of a conventional bracing member. The slip load was controlled using disc spring washers. $\mathrm{Li}$ and Reinhorn [7] performed the experimental and analytical study on the seismic behavior of a reinforced concrete building with friction dampers. Moreover, Mualla and Beleve [8] proposed a rotational friction damper. This damper is composed of steel plates, preloaded bolts, and two friction pad discs located between the steel plates. Colajannio and Papia [9] performed analysis on the seismic behavior of braced frames with friction dampers. $\mathrm{Xu}$ and $\mathrm{Ng}$ [10] conducted an analytical investigation of seismic response control of structure with friction dampers. Lee et al. [11] proposed a method to assess the slip force of friction dampers in building structure based on story shear force distribution. Vaseghi Amiri et al. [12] investigated eccentric braced steel frames (systems behavior) with friction damper using finite-element analysis, and the results showed that friction damper decreased structure's seismic response, compared to EBF, particularly in tall buildings. Panikos et al. [13] performed experiments on a friction device consisting of a set of rotational friction flanges and a link element for strengthening RC and steel buildings. Montuori et al. [14] suggested a methodology to design a MR-frame and bracing system with friction dampers. Maleki and Mahjoubi [15] introduced a new passive damper called the dual-pipe damper and investigated the hysteresis behavior of damper through experimental and analytical approaches. Cheng and Chen [16] studied seismic performance of a rocking bridge pier substructure with friction dampers through 32 shake table tests and compared the results with analytical models. Sanati et al. [17] introduced a rotational friction viscoelastic damper which dissipates the energy using friction and viscoelastic pads, simultaneously. Mirzabagheri et al. [18] tested a rotational friction damper with two and three units and compared the results with one-unit dampers. They also evaluated the performance of the damper in frames using nonlinear time history analysis, and concluded that increasing the number of units of damper increases the energy dissipation capacity of the damper.

This paper aims to study the hysteresis behavior of the rotational friction damper proposed by Mualla and Beleve [8] with different friction materials. Since then, the experimental analysis is performed on the damper specimens with four friction pads: aluminum, galvanized steel, stainless steel, and steel (St-37). The cyclic loading is applied on damper specimens according to FEMA-356 [17] loading protocol. The hysteresis behavior and energy dissipation capacity of damper specimens with four different friction materials are studied according to FEMA-356 [19] acceptance criteria. Moreover, the tribological properties of friction pads at the end of cyclic loading are studied.

\section{Theory of friction damper behavior}

Friction forces resulting from the relative motion of two surfaces in contact are a source of energy dissipation. Friction dampers are designed to dissipate energy using the friction across the interface of two sliding bodies. The damper used in this paper is composed of steel plates and circular friction pad discs located between the steel plates. Figure 1 shows the damper details. The steel plates and friction discs provide the frictional surface area. The preloaded M16 class 10.9 bolts clamp plates and discs firmly to each other. The compression force applied on the friction pads is maintained by these preloaded bolts. Disc spring washers are used to control a constant clamping force. Hardened washers are located between these springs and steel plates to protect steel plates during compression [8]. Lateral loads applied on a structural frame during cyclic loading or earthquake excitement cause the girder to be displaced horizontally, and axial load and friction forces develop at the interface of steel plates and friction pads [8]. The action mechanism of the damper and the possible installation method of the damper in a building frame are shown in Figures 2 and 3, respectively. As is shown, the damper can be arranged within bracing systems.

\section{Experimental program}

In this research, in order to investigate hysteresis behavior of the damper using different friction materials, the following friction materials are studied experimentally:

- Aluminum;

- Galvanized steel;

- Stainless steel;

- Steel (St-37, Fy = $\left.2400 \mathrm{~kg} / \mathrm{cm}^{2}\right)$.

The friction coefficients of friction materials on steel, studied in this paper, are presented in Table 1. The preloaded force $(F)$ and torque of bolts are also presented in Table 1. The texture of materials is also

Table 1. Tested Specimens properties.

\begin{tabular}{cccc}
\hline Material & $\begin{array}{c}\text { Friction } \\
\text { coefficient } \\
\text { (sliding) }\end{array}$ & $\begin{array}{c}\boldsymbol{F} \\
(\mathbf{k N})\end{array}$ & $\begin{array}{c}\text { Torque } \\
(\mathbf{N . m})\end{array}$ \\
\hline Aluminum on steel & 0.47 & 41 & 300 \\
Galvanized steel on steel & 0.45 & 89 & 300 \\
Stainless steel on steel & 0.30 & 110 & 300 \\
Steel on steel & 0.57 & 85 & 300 \\
\hline
\end{tabular}




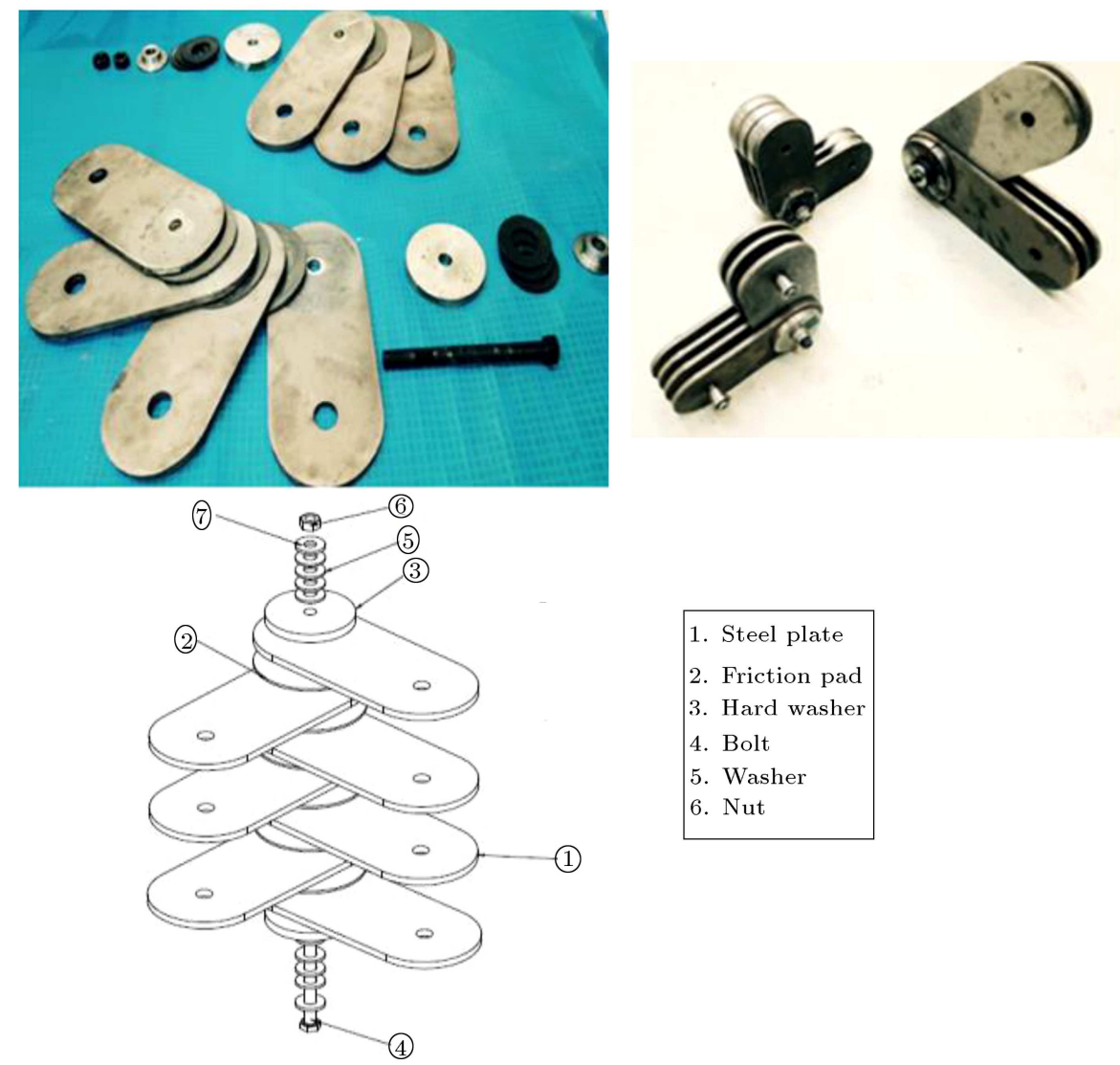

Figure 1. Friction damper detail.

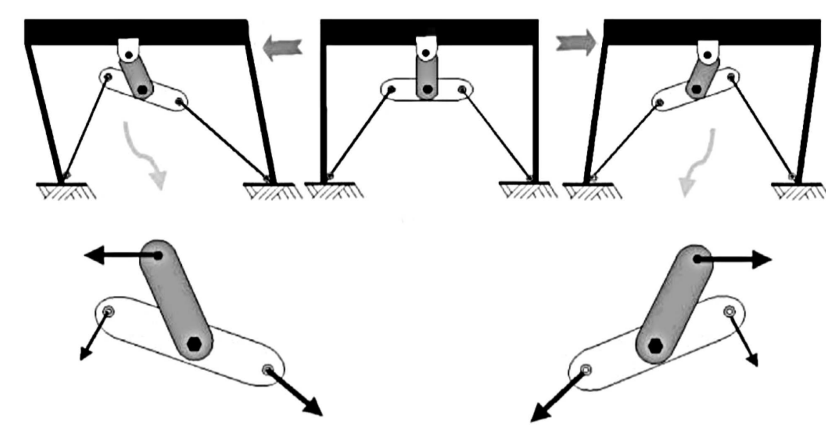

Figure 2. Principal of action of the rotational friction damper [8].

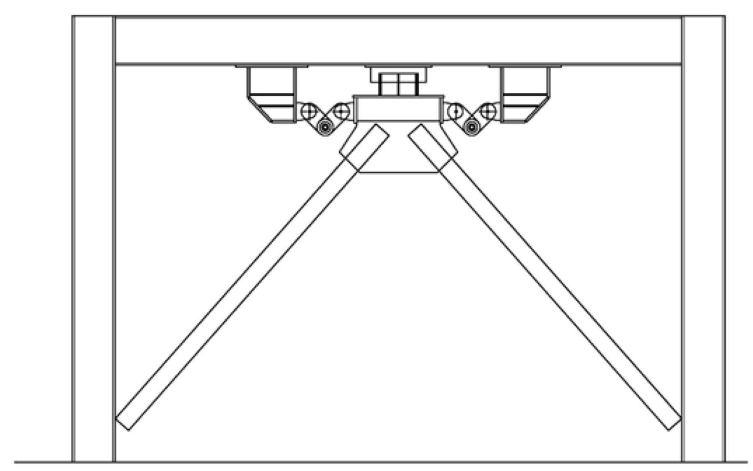

Figure 3. Installation of damper in a structural frame. displayed in Figure 4. The thickness and diameter of friction pads used in the damper are $2 \mathrm{~mm}$ and 150 $\mathrm{mm}$, respectively.

Four damper specimens with different friction pads are constructed. A torque meter is used to measure the tightening torque of each damper specimen. Table 1 represents the tightening torques and preloaded forces of bolts.

\subsection{Experiment setup}

The experimental analysis is performed using a rotational friction damper with the expected capacity of $50 \mathrm{kN}$. A $100 \mathrm{KN}$ capacity hydraulic jack is used to apply cyclic loads. The thickness and dimension of friction pads are $2 \mathrm{~mm}$ and $150 \mathrm{~mm}$, respectively. A series of displacement controlled cyclic loadings in two amplitudes, according to FEMA-356 [18] protocols, are applied to each damper specimen. Initially, 20 loading cycles with $20 \mathrm{~mm}$ amplitude and, then, another 20 loading cycles with $26 \mathrm{~mm}$ amplitude are applied. The test setup is shown in Figure 5. A load cell and a LVDT are used to measure load and displacement at the end of each loading cycle, respectively. The force-displacement hysteresis behavior of specimens is plotted. The displacement history is shown in Figure 6 . 


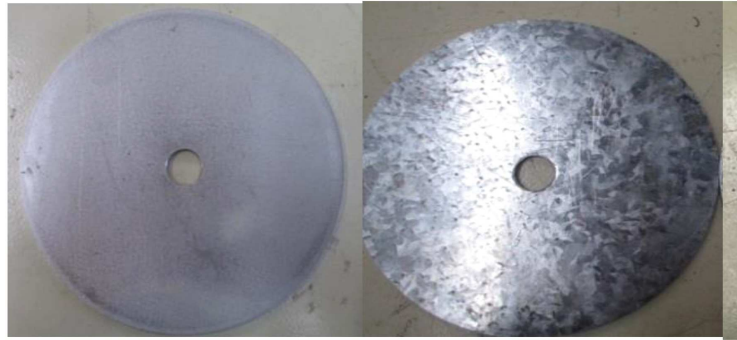

Aluminum

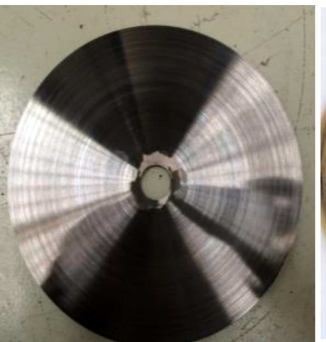

Stainless steel

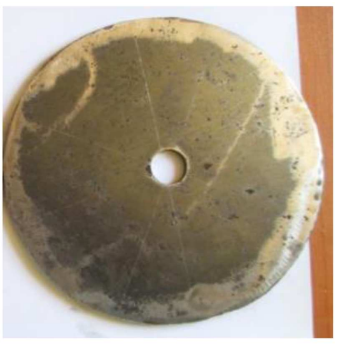

Steel

Figure 4. Friction pads before experiment.
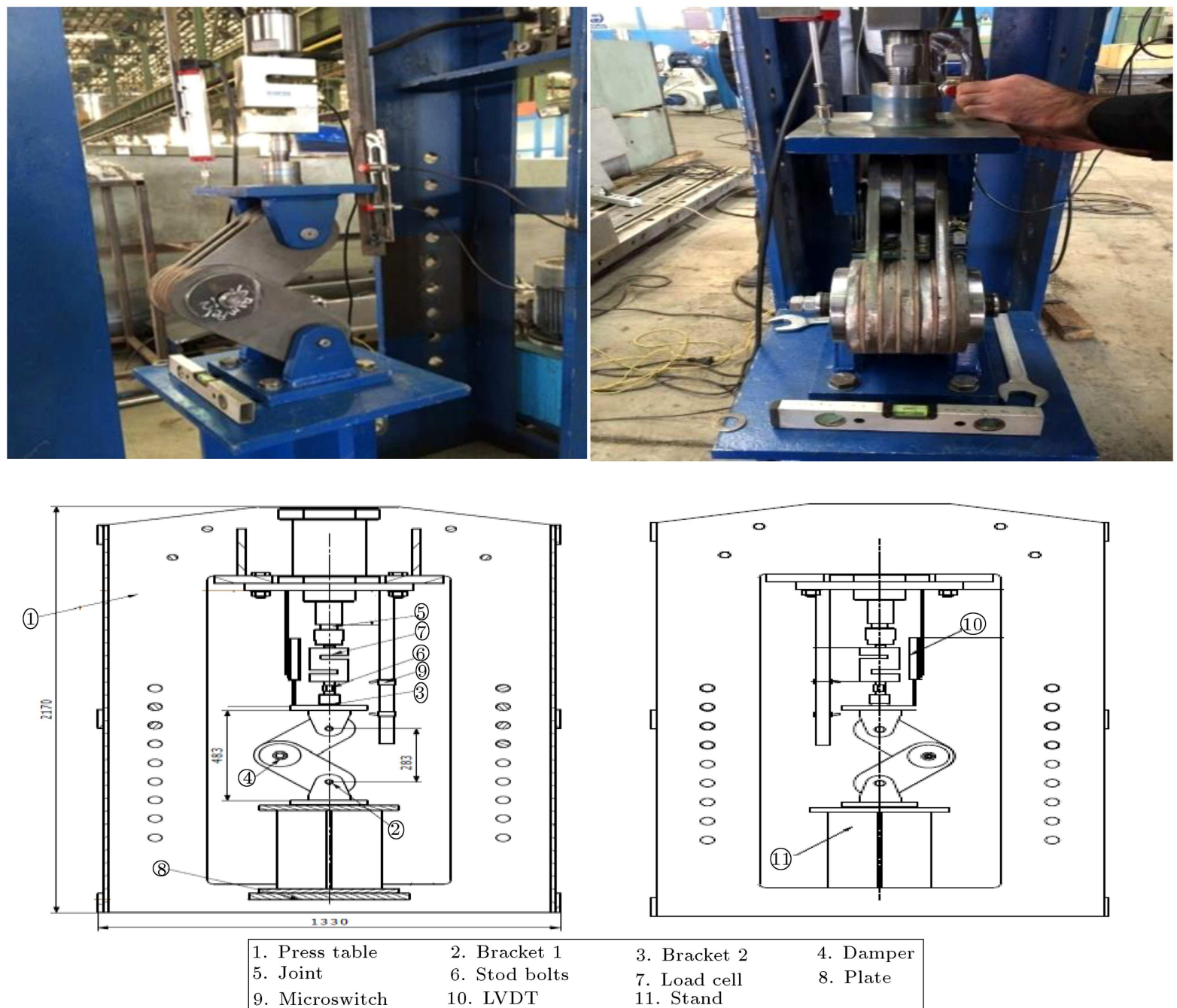

Figure 5. The components of test setup.

\section{Experiment results}

\subsection{Hysteresis curves of damper specimens}

The force-displacement hysteresis curves of damper specimens with four friction materials are obtained from the experimental analysis and represented in Figure 7. According to the tests' results, the damper with aluminum pads shows stable hysteresis behavior and negligible strength degradation, while the loading capacity of damper with galvanized steel increases during cyclic loading due to considerable plastic deformation of the surfaces in contact. In the case of stainless steel, the damper exhibits relatively stable hysteresis loops except the pin fractured during cyclic loading. In the case of steel (St-37) friction pads, the damper shows stable hysteresis loops and small strength degradation. 


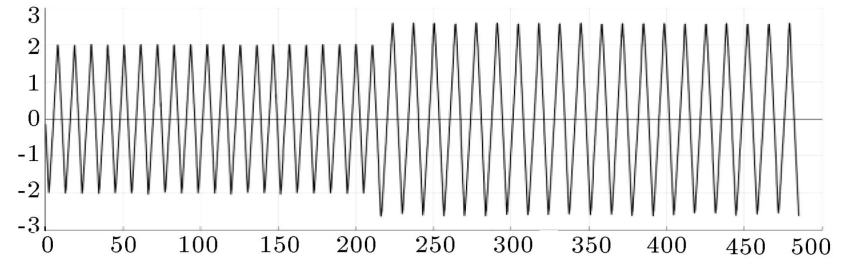

Figure 6. Displacement loading history.

\subsection{The test result assessment}

FEMA-356 [17] introduces some experimental tests and acceptance criteria to approve the displacementdependent energy dissipation devices. The acceptance criteria are described below:

1. The force-displacement response of a displacementdependent device is a function of the relative displacement between each end of the device. The effective stiffness $\left(k_{\text {eff }}\right)$ of dampers is calculated for each cycle of deformation as follows [18]:

$$
k_{e f f}=\frac{\left|F^{-}\right|+\left|F^{+}\right|}{\left|\Delta^{-}\right|+\left|\Delta^{+}\right|},
$$

where forces $F^{-}$and $F^{+}$are calculated at displacements $\Delta^{-}$and $\Delta^{+}$, respectively.

According to FEMA-356, the effective stiffness $\left(k_{e f f}\right)$ of dampers for any one cycle should not differ more than $\pm 15 \%$ from the average effective stiffness calculated from all cycles in the test [18].

2. The equivalent viscous damping of a friction damper $\left(b_{\text {eff }}\right)$ exhibiting stiffness is calculated for each cycle of deformation as follows [18]:

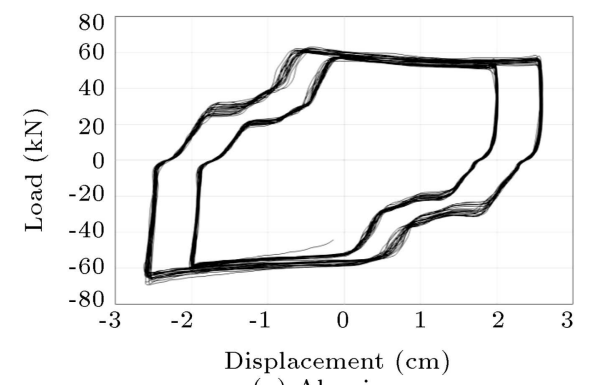

(a) Aluminum

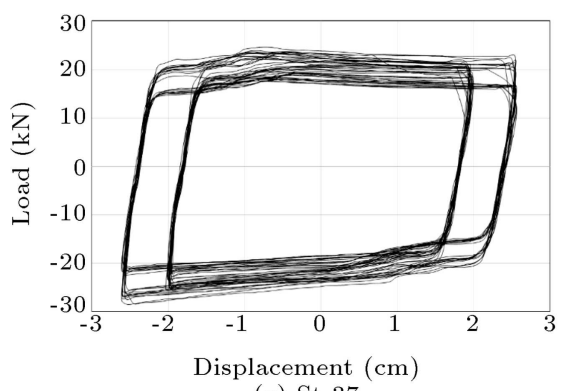

(c) St-37

$$
b_{\text {eff }}=\frac{1}{2 \pi} \frac{W_{D}}{k_{e f f} \Delta_{\text {ave }}^{2}}
$$

where $k_{\text {eff }}$ is calculated in Eq. (2), and $W_{D}$ is the area enclosed by one complete cycle of the forcedisplacement response of damper during cyclic loading test. $\Delta_{\text {ave }}$ is equal to the average of the values of displacements $\Delta^{-}$and $\Delta^{+}$. The obtained values of $b_{\text {eff }}$ should be between $\pm 15 \%$ from the average values of $b_{\text {eff }}[18]$.

3. The amount of energy dissipated by damper during cyclic loading is calculated by evaluating area of the hysteresis loop $\left(W_{D}\right)$ based on FEMA-356. The area of the hysteresis loop at the end of cyclic loading should not differ by more than $\pm 15 \%$ from the average area of the 20 test cycles.

4. The forces at zero displacements are calculated for dampers, and the average values are estimated and compared with $\pm 15 \%$ from the average value and calculated for all cycles in that test [17].

In this paper, the experiment's results are investigated according to FEMA-356 [18] acceptance criteria and are presented in Figures 8-11. According to the test results, the damper with aluminum pads meets all approval conditions, while some acceptance criteria are not satisfied in the case of stainless steel, galvanized steel, and St-37.

\subsection{Friction materials after cyclic loading}

The friction materials used for rotational friction damper should show sufficient resistance under tension or compression loads and low fragmentation during

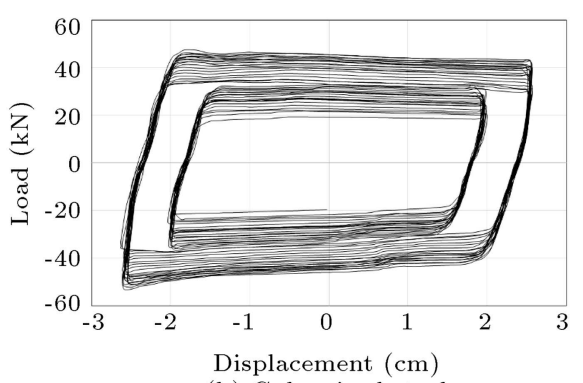

(b) Galvanized steel

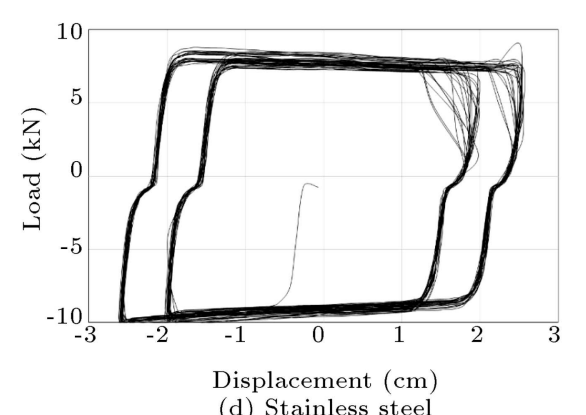

(d) Stainless steel

Figure 7. Hysteresis behavior of dampers with four friction materials. 

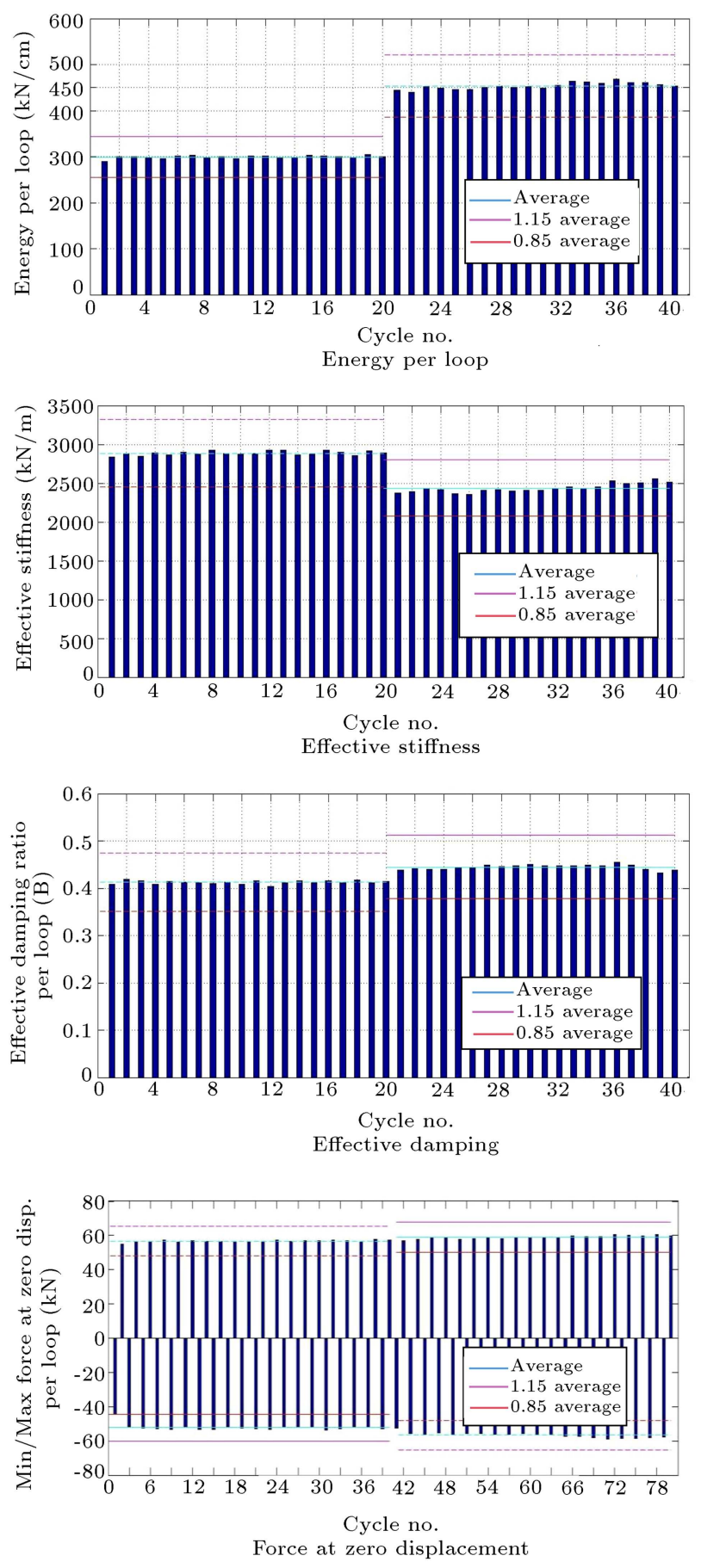

Figure 8. The test results assessment according to FEMA-356 acceptance criteria (aluminum).

cyclic loading. Figure 12 shows the friction pads at the end of cyclic loading. As observed, aluminum pads show low abrasion resistance under cyclic loading, and aluminum powders are observed on the pad surface at the end of loading. The galvanized steel pads show extensive abrasion at the end of cyclic loading. In the case of St-37, the friction pad shows low abrasion resistance under cyclic loading, while the abrasion of stainless steel pads is negligible.
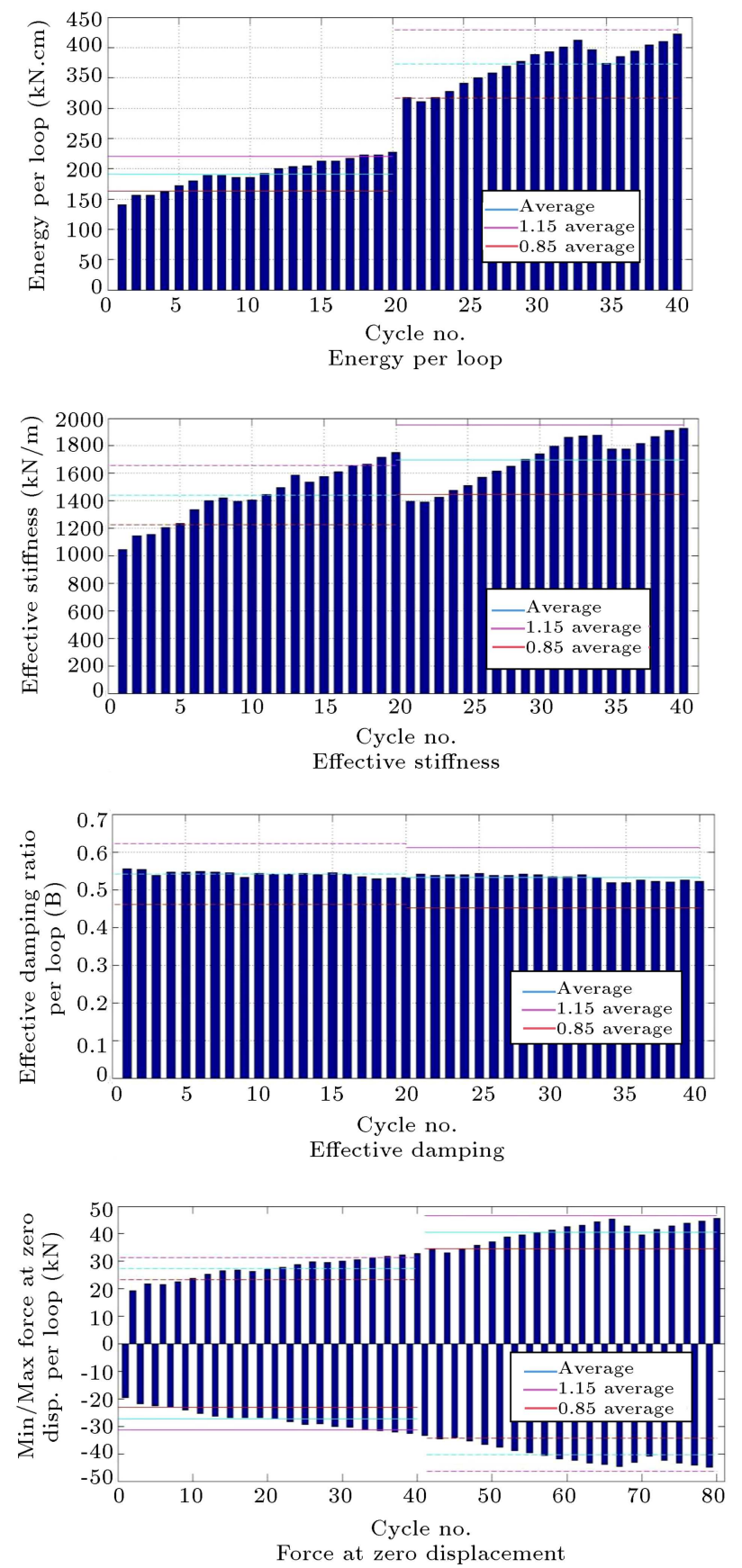

Figure 9. The test results assessment according to FEMA-356 acceptance criteria (galvanized steel).

\section{Conclusion}

In this paper, the cyclic behavior of a rotational friction damper with different friction materials was studied through an experimental program. The tests' friction materials include aluminum, galvanized steel, stainless steel, and steel (St-37). The cyclic loading is applied to damper specimens according to FEMA-356 [18] protocols. The test results are investigated according to FEMA-356 [18] acceptance criteria. The results are summarized below: 

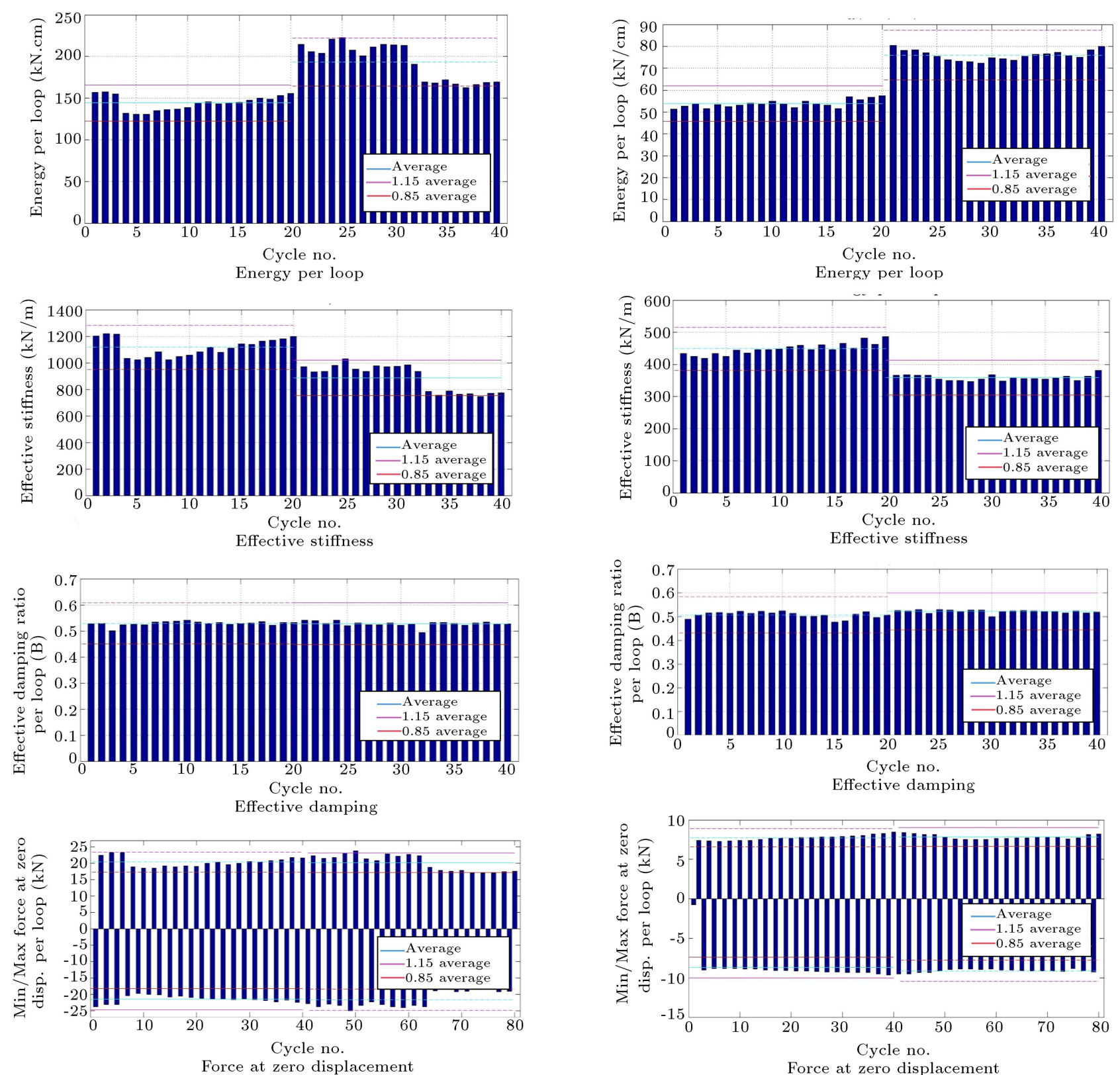

Figure 10. The test results assessment according to FEMA-356 acceptance criteria (St-37).

- The aluminum and St-37 exhibit more stable hysteresis behavior and low strength degradation, in comparison to the other friction materials;

- The aluminum, galvanized steel, and steel pads show extensively high abrasion at the end of cyclic loading, while stainless steel shows low abrasion under cyclic loading, as compared to the other tested friction materials;

The aluminum meets the approval consideration for passive energy dissipation devices presented by FEMA-356, while, in the case of the galvanized steel and St-37, some acceptance criteria are not satisfied;

Figure 11. The test results assessment according to FEMA-356 acceptance criteria (stainless steel).

- According to the results, although the damper with aluminum pads satisfied all FEM-356 acceptance criteria and can be used in high cyclic loading, the abrasion of aluminum pad under cyclic loading is significant. Therefore, if the damper with aluminum pads is used in seismic design of structures, the aluminum pads of damper should be replaced by new ones after earthquake.

Acknowledgement

This research is a part of the $\mathrm{PhD}$ thesis of Mr. M. Anoushehei in Tarbiat Modares University and funded 


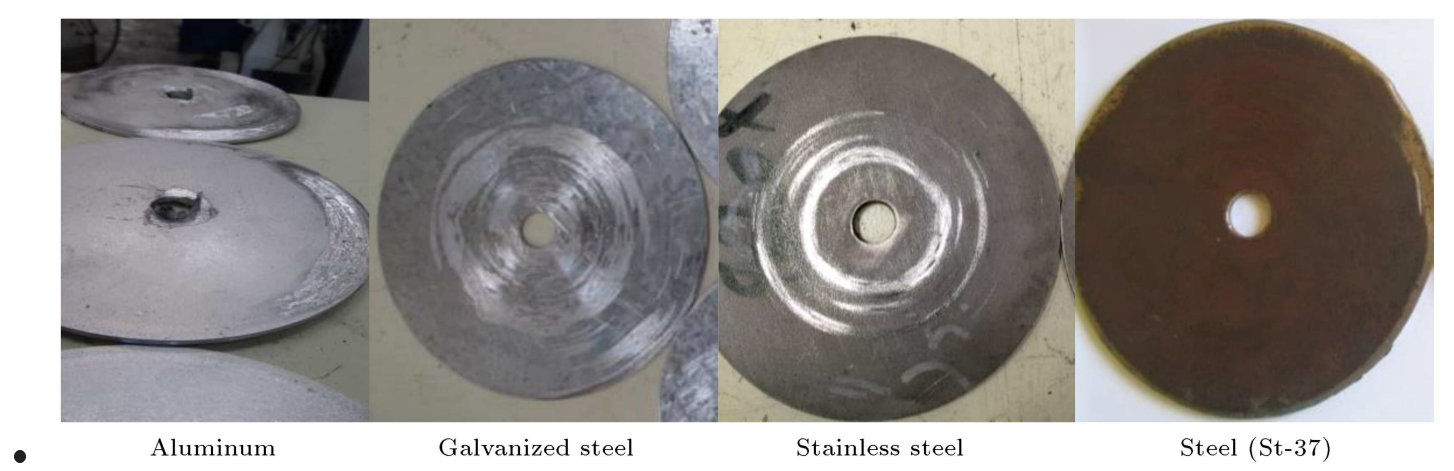

Figure 12. Friction materials after experiment.

by the SAAB Steel Company. The authors wish to thank the management of the SAAB Steel Company and its technical staff who contributed to the success of the experimental program through their valuable support and expertise.

\section{References}

1. Soong, T.T. and Dargush, G.F. Passive Energy Dissipation Systems in Structural Engineering, John Wiley \&6 Sons Chichester, ISBN 0-471-96821-8 (1997).

2. Kelly, J.M., Skinner, R.I., and Heine, A.J. "Mechanisms of energy absorption in special devices for use in earthquake-resistant structures", J. Earthq. Eng., 5(3), pp. 63-88 (1972).

3. Latour, M., Piluso, V., and Rizzano, G. "Experimental analysis on friction materials for supplemental damping Devices", Construct. Build. Mat., 65, pp. 159-176 (2014).

4. Pall, A. and Marsh, C. "Response of friction damped braced frames", J. Struct. Div., 108(6), pp. 1313-1323 (1981).

5. Constantinou, M.C., Mokha. A., and Reinhorn, A.M. "Teflon bearings in base isolation, II: modeling", $J$. Struct. Eng., $116(2)$, pp. 455-74 (1990).

6. Tremblay, R. and Stiemer, S. "Energy dissipation through friction bolted connections in concentrically braced steel frames", ATC 17-1, Seminar Seismic Isolation, pp. 557-568 (1993).

7. Li, C. and Reinhorn, A.M. "Experimental and analytical investigation of seismic retrofit of structures with supplemental damping: Part II - Friction devices", Technical Report NCEER-950009, Buffalo (NY): State University of New York at Buffalo (1995).

8. Mualla, I. and Beleve, B. "Seismic response of steel frames equipped with a new friction damper device under earthquake excitation", J. Eng. Struct., 24(3), pp. 365-371 (2002).

9. Colajannio, P. and Papia, M. "Seismic response of braced frames with and without friction dampers", Eng. Struct., 17, pp. 129-40 (1995).
10. Xu, Y.L. and Ng, C.L. "Seismic response control of a building complex utilizing passive friction damper", Experimental Investigation Earthq. Eng. and Struct. Dyn., 35, pp. 657-677 (2006).

11. Lee, S.H., Park, J.H., Lee, S.K., and Min, K.W. "Allocation and slip load of friction dampers for a seismically excited building structure based on story shear force distribution", Eng. Struct., 30, pp. 930-40 (2008).

12. Vaseghi, A., Navayinia, B., and Navaei, S. "Evaluation of performance of eccentric braced frame with friction damper", Struct. Eng. Mech., 39(5), pp. 717-732 (2011).

13. Papadopoulos, P.K., Salonikios, T.N., Dimitrakis, S.A., and Papadopoulos, A.P. "Experimental investigation of a new steel friction device with link element for seismic strengthening of structures", Struct. Eng. Mech., 46, p. 4 (2013).

14. Montuori, R., Nastri, E., and Piluso, V. "Theory of plastic mechanism control for the seismic design of braced frames equipped with friction dampers", Mechanics Research Communications, 58, pp. 112-123 (2014).

15. Maleki, S. and Mahjoubi, S. "Dual-pipe damper", $J$. Construct. Steel Res., 85, pp. 81-91 (2013).

16. Cheng, Ch. and Chen, F. "Seismic performance of a rocking bridge pier substructure with frictional hinge dampers", Smart. Struct. Sys., 14(4), pp. 501-516 (2014).

17. Sanati, M., Khadem, S.E., Mirzabagheri, S., Sanati, H., and Khosravieh, M.Y. "Performance evaluation of a novel rotational damper for structural reinforcement steel frames subjected to lateral excitations", Earthq. Eng and. Eng., 13, pp. 75-84 (2014).

18. Mirzabagheri, S., Sanati, M., Aghakouchak, A.A., and Khadem, S. "Experimental and numerical investigation of rotational friction dampers with multi units in steel frames subjected to lateral excitation", Arch of. Civil. Mech. Eng., 15, pp. 479-491 (2015).

19. FEMA-356 "Pre-standard and Commentary for the Seismic Rehabilitation of Buildings", Federal Emergency Management Agency (FEMA), Washington D.C. (2000). 


\section{Biographies}

Majid Anoushehei is currently a PhD Student of Structural Engineering at the Department of Civil and Environmental Engineering, Tarbiat Modares University, Tehran, Iran. He received his MSc degree in structural engineering. His field of study is structural engineering.

Farhad Daneshjoo is a Professor of Civil Engineering at the Department of Civil and Environmental Engineering, Tarbiat Modares University, Tehran, Iran. He received his $\mathrm{PhD}$ degree in Civil Engineering in West Minister University (Central London Polytechnic). His research interests are structural and earthquake engineering.

Shima Mahboubi is currently a PhD student of Earthquake Engineering at the Department of Civil Engineering, Shahid Beheshti University, Tehran, Iran. She received her MSc degree in Earthquake Engineering in 2011. Her field of study is earthquake en gineering.

Mohammad Hadi Hashemi received the MSc degree in Mechanical Engineering from the Amirkabir University, Tehran, Iran. He works as a Mechanical Engineer in SAAB Steel Development Company, Qazvin, Iran. 